\title{
Article \\ Evaluating the Influence of a G-Quadruplex Prone Sequence on the Transactivation Potential by Wild-Type and/or Mutant P53 Family Proteins through a Yeast-Based Functional Assay
}

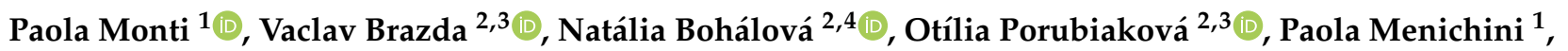 \\ Andrea Speciale ${ }^{1}$, Renata Bocciardi ${ }^{5,6}\left(\mathbb{D}\right.$, Alberto Inga ${ }^{7, *}$ and Gilberto Fronza $1, *(\mathbb{D})$
}

1 Mutagenesis and Cancer Prevention Unit, IRCCS Ospedale Policlinico San Martino, 16132 Genoa, Italy; paola.monti@hsanmartino.it (P.M.); paola.menichini@hsanmartino.it (P.M.); andrea.speciale@hsanmartino.it (A.S.)

2 Institute of Biophysics of the Czech Academy of Sciences, Královopolská 135, 61265 Brno, Czech Republic; vaclav@ibp.cz (V.B.); natalia.bohalova@ibp.cz (N.B.); o.porubiakova@gmail.com (O.P.)

3 Department of Food Chemistry and Biotechnology, Faculty of Chemistry, Brno University of Technology, Purkyňova 118, 61200 Brno, Czech Republic

4 Department of Experimental Biology, Faculty of Science, Masaryk University, Kamenice 5, 62500 Brno, Czech Republic

5 Department of Neurosciences, Rehabilitation, Ophthalmology, Genetics, Maternal and Child Health (DiNOGMI), University of Genoa, Largo P. Daneo 3, 16132 Genoa, Italy; bocciardi@unige.it

Citation: Monti, P.; Brazda, V.; Bohálová, N.; Porubiaková, O.; Menichini, P.; Speciale, A.; Bocciardi, R.; Inga, A.; Fronza, G. Evaluating the Influence of a G-Quadruplex Prone Sequence on the Transactivation Potential by Wild-Type and/or Mutant P53 Family Proteins through a Yeast-Based Functional Assay. Genes 2021, 12, 277. https://doi.org/ 10.3390/genes12020277

Academic Editor: Alvaro Galli

Received: 21 January 2021

Accepted: 10 February 2021

Published: 15 February 2021

Publisher's Note: MDPI stays neutral with regard to jurisdictional claims in published maps and institutional affiliations.

Medical Genetics Unit, IRCCS Istituto Giannina Gaslini, via G. Gaslini 5, 16147 Genoa, Italy

7 Laboratory of Transcriptional Networks, Department of Cellular, Computational and Integrative Biology, CIBIO, University of Trento, via Sommarive 9, 38123 Trento, Italy

* Correspondence: alberto.inga@unitn.it (A.I.); gilberto.fronza@hsanmartino.it (G.F.); Tel.: +39-0461-283714 (A.I.); +39-010-5558225 (G.F.)

\begin{abstract}
P53, P63, and P73 proteins belong to the P53 family of transcription factors, sharing a common gene organization that, from the P1 and P2 promoters, produces two groups of mRNAs encoding proteins with different $\mathrm{N}$-terminal regions; moreover, alternative splicing events at $\mathrm{C}$ terminus further contribute to the generation of multiple isoforms. P53 family proteins can influence a plethora of cellular pathways mainly through the direct binding to specific DNA sequences known as response elements (REs), and the transactivation of the corresponding target genes. However, the transcriptional activation by P53 family members can be regulated at multiple levels, including the DNA topology at responsive promoters. Here, by using a yeast-based functional assay, we evaluated the influence that a G-quadruplex (G4) prone sequence adjacent to the p53 RE derived from the apoptotic PUMA target gene can exert on the transactivation potential of full-length and N-terminal truncated P53 family $\alpha$ isoforms (wild-type and mutant). Our results show that the presence of a G4 prone sequence upstream or downstream of the P53 RE leads to significant changes in the relative activity of P53 family proteins, emphasizing the potential role of structural DNA features as modifiers of P53 family functions at target promoter sites.
\end{abstract}

Keywords: P53 family; yeast; G-quadruplex (G4) prone sequence; wild-type and mutant P53/P63 proteins; transactivation potential

\section{Introduction}

The P53 family of transcription factors (TFs) is composed of P53, P63, and P73 proteins [1-3] that share an $\mathrm{N}$-terminal transactivation domain, a central sequence-specific DNA-binding domain, and a C-terminal tetramerization domain. At the C-terminus, a sterile $\alpha$ motif domain (SAM), probably involved in protein-protein interactions, is present only in P63 and P73 proteins. These TFs, by inducing a plethora of target genes, can influence different cellular pathways including proliferation, apoptosis, DNA repair, angiogenesis, senescence, metabolism, and differentiation [4,5]. 
To further complicate the scenario, multiple P53, P63, and P73 isoforms are generated from mechanisms of alternative usage of promoters, splicing sites, and/or translation initiation sites [6]. All P53 family members can be transcribed starting from different promoters resulting in variants with different $\mathrm{N}$-terminal sequences (i.e., full-length P53, $\triangle \mathrm{N} 40 \mathrm{P} 53, \mathrm{TAP} 63$, and TAP73 from the P1 promoter, and $\triangle \mathrm{N} 133 \mathrm{P} 53, \triangle \mathrm{N} 160 \mathrm{P} 53, \Delta \mathrm{NP} 63$, and $\triangle$ NP73 from the P2 promoter). Moreover, $\mathrm{C}$-terminal variations occur as a result of alternative splicing, giving rise to at least three different isoforms (i.e., $\alpha, \beta, \gamma$ for P53 and P63; $\alpha, \beta, \gamma, \delta, \varepsilon, \zeta, \eta$ for P73).

Despite these similarities, the overlap in cellular functions between P53, P63, and P73 proteins is limited. TP53 is the most frequently mutated gene in human sporadic cancers and TP53 germ-line mutations are associated with the development of the cancer-prone Li-Fraumeni and Li-Fraumeni-like syndromes [7]. Conversely, the TP63 gene, being critical for the correct development of ectodermal-derived tissues, is associated with the occurrence of a subset of ectodermal dysplasia syndromes (i.e., P63-associated disorders) due to TP63 germ-line mutations [3,8,9]. Lastly, P73 contributes to neural and immune system functions but no genetic disorder has been linked to the gene [10,11], possibly because any such TP73 mutation might produce severe defects that are embryonically lethal.

To regulate genes expression, the P53 family members, acting mainly as TFs, share a DNA response element (RE) which consists of two degenerate decameric sequences separated by a variable spacer [RRRCWWGYYY-(n)-RRRCWWGYYY $(R=$ purine; $W=\mathrm{A} / \mathrm{T}$; $Y=$ pyrimidine; $n=0-13)$ ] [12-14]. Even though the DNA-binding specificities for P53, $\mathrm{P} 63$, and P73 appear comparable, differences for certain DNA sequences have been reported [15-17]. Moreover, gene expression and genome-wide occupancy studies reveal a partial overlap between gene networks of P53 family members [18]; in fact, many genes appeared to be exclusively targeted by one of the P53 family members [19-22].

Recently, it was shown that DNA topology can contribute to regulating P53 DNA affinity and specificity $[23,24]$. It was demonstrated that $\mathrm{P} 53$ protein binds to various DNA structures stabilized by DNA topological stress such as G-quadruplex (G4)-forming sequences, cruciforms, and other local DNA structures [24-26], as recently reviewed [27]. Furthermore, some P53 mutants have a high predisposition for binding to Transcription Start Site-associated G/C-rich regions, particularly G4s, which are prone to form non-B DNA structures [28].

The yeast Saccharomyces cerevisiae is a recognized model system for understanding different aspects of human biology. Thanks to the evolutionary conservation of basic components of the transcription machinery, many TFs, including P53 family proteins, when ectopically expressed in yeast cells can modulate the expression rates of reporter genes, acting through promoters engineered to contain cognate target REs [29-31]. Moreover, a particularly versatile approach based on the Delitto Perfetto technique is available in yeast to target the selected genomic loci through homologous recombination [32], leading to the development of a matrix of results where the functional interaction of TFs binding sites with other nearby cis-elements can also be evaluated [33].

Based on the assumption that DNA topology can be an important factor in establishing P53-dependent transactivation at target genomic sites, we previously evaluated the influence of a G4 DNA prone sequence in the proximity of a P53 RE on the transactivation potential of full-length and N-terminal truncated P53 $\alpha$ isoforms [34]. The results showed that a G4 prone sequence alone is not sufficient for transcriptional activation by the different P53 $\alpha$ isoforms (i.e., full length, $\Delta N 40, \Delta N 133$, and $\Delta N 160$ ); however, its presence in proximity to a P53 RE leads to significantly different fold changes in transcriptional activity and dynamics between the co-expressed P53 isoforms.

Here, by using the same experimental approach in yeast, we extended this study to $\triangle \mathrm{N}$ and TA $\alpha$ variants of P63 and P73 proteins. Moreover, since human germ-line TP53 and TP63 mutations are responsible for the development of specific genetic disorders and considering that TP53 somatic mutations are frequent in human cancers, we also evaluated the effect of the presence of the same G4 prone sequence on the functional features of 
mutant P53 and P63 proteins. The results obtained highlight how the presence of a G4 prone sequence adjacent to a P53 RE impact the transcriptional activity of wild-type and mutant proteins from all P53 family members.

\section{Materials and Methods}

\subsection{Yeast Strains and Media}

A panel of isogenic reporter strains, which differ only in the presence and position of a P53 RE [from PUMA (p53 up-regulated modulator of apoptosis) target gene: $5^{\prime}$-CTGCAAGTCCTGACTTGTCC-3'] and a G4 prone sequence [from KSHV (Kaposi sarcoma-associated herpes virus): 5'-GGGGCGGGGGACGGGGGAGGGG-3'] both located upstream of the luciferase reporter gene (LUC1) were used [34-36]. The PUMA $\mathrm{RE}$ was selected in virtue of its moderate strength and for the presence of physiological G4 sequences around the RE in the human promoter. This panel includes yLFM-PUMA (PUMA RE), yLFM-KSHV (G4), yLFM-KSHV-PUMA (G4 upstream of PUMA RE), and yLFM-PUMA-KSHV (G4 downstream of PUMA RE) strains. Yeast cells were grown in YPDA medium (1\% yeast extract, $2 \%$ peptone, $2 \%$ dextrose, $200 \mathrm{mg} / \mathrm{L}$ adenine) or selective medium (with or without $2 \%$ agar), containing dextrose or raffinose as a carbon source plus adenine $(200 \mathrm{mg} / \mathrm{L})$, but in the absence of tryptophan and/or leucine (Sigma-Aldrich, Saint Louis, MO, USA; Biokar Diagnostics, Allonne, France). Galactose (Sigma-Aldrich, Saint Louis, MO, USA) was added to the medium for the modulation of P53 family proteins expression under the inducible GAL1, 10 promoter [37]. Yeast manipulations were performed, as previously described [33,38].

\subsection{Yeast Vectors}

Wild-type P53 [full length (i.e., P53 $\alpha$ corresponding to the well-known 393 aminoacids long protein) and $\Delta \mathrm{N} 40 \alpha), \mathrm{P} 63(\Delta \mathrm{N} \alpha$ and TA $\alpha)$ and P73 $(\Delta \mathrm{N} \alpha$ and TA $\alpha)$ proteins were expressed by yeast pTSG-based vectors (inducible GAL1,10 promoter, TRP1) [39-41] as well as mutant full-length P53 (i.e., R175H and R282W) and $\Delta \mathrm{NP} 63 \alpha$ (i.e., G134V and $\mathrm{R} 204 \mathrm{~W})$ proteins [41,42]. For co-expression experiments vectors expressing wild-type full-length P53 and $\triangle$ NP63 $\alpha$ under the constitutive ADH1 promoter [pLS76 (LEU2) and pLS- $\triangle$ NP63 $\alpha$ (LEU2), respectively] were used along with the yeast plasmids described above [41,43]. Empty vectors pRS314 (TRP1) and pRS315 (LEU2) were available.

\subsection{Yeast Functional Assay}

Quantitative functional assays were performed according to the miniaturized protocol we developed $[33,38]$. Briefly, yeast transformants were grown at $30{ }^{\circ} \mathrm{C}$ in a selective medium containing 1\% Galactose in order to modulate P53 family proteins expression; after $8 \mathrm{~h}$ of growth OD $(600 \mathrm{~nm})$ was measured. Twenty $\mu \mathrm{L}$ of cell suspension was transferred into a white plate and mixed with an equal volume of PLB buffer 2X (Promega Italia, Milan, Italy) to obtain the lysis of yeast cells. After 15 min of shaking at room temperature, firefly luciferase substrate $(20 \mu \mathrm{L}$, Bright Glo, Promega) was added. Luciferase activity was measured using a multilabel plate reader (Mithras LB940, Berthold Technologies, Calmbacher, Germany). The transactivation ability of wild-type and mutant P53 family proteins was measured as relative light units (RLUs) and normalized first to the cultures' absorbance $(600 \mathrm{~nm})$. Then the fold changes were calculated using as reference the normalized RLUs measured from cultures of each yeast reporter strains transformed with the appropriate empty vector(s) (pRS314 or pRS314 + pRS315 depending on the experiments). The relative activity from the same fold change data was calculated by comparing the activity of a protein/allele of interest with the activity of a chosen reference. Data derive from two technical replicates with at least two biological replicates except for yLFM-KSHV strain measurements (i.e., three biological replicates). 


\subsection{Statistical Analysis}

Statistical analysis was performed by using two-way ANOVA and Tukey's multiple comparisons test or one-way ANOVA and Dunnett's multiple comparisons test (Graphpad Prism 9) $\left({ }^{*} p<0.05 ;{ }^{* *} p<0.01 ;{ }^{* * *} p<0.001 ;{ }^{* * *} p<0.0001\right.$; ns: not significant).

\section{Results}

3.1. The Presence of a G4 Prone Sequence Adjacent to a P53 RE Alters the Relative Activity of Wild-Type P53 Family Proteins

To elucidate the role of a G4 prone sequence on the transcriptional activity of P53 family members, we focused our analysis on $\alpha$ isoforms including $\Delta$ N40P53, full-length P53, $\triangle \mathrm{NP} 63, \mathrm{TAP} 63, \triangle \mathrm{NP73}$, and TAP73 $(\triangle \mathrm{N} 40 \mathrm{P} 53, \triangle \mathrm{NP63}$, and $\triangle \mathrm{NP73}$ were indicated as $\triangle \mathrm{N}$ variants; full-length P53, TAP63, and TAP73 were indicated as TA variants) by using a yeast-based functional assay. Consistent with previous observations regarding P53, wild-type P63 and P73 proteins ( $\triangle \mathrm{N}$ and TA variants) were unable to activate transcription (measured as fold change over empty vector) from a G4 prone sequence (yLFM-KSHV) (Figure 1A, right panel) compared to the control yLFM-PUMA (Figure 1A, left panel). Similarly, the presence of the same G4 prone sequence upstream (yLFM-KSHV-PUMA) or downstream (yLFM-PUMA-KSHV) of the PUMA P53 RE led to a significant decrease in transactivation (Figure 1B), especially in the strain where the G4 prone sequence is downstream of the RE; in this strain, the full-length P53, TAP63 $\alpha$, and TAP73 $\alpha$ showed an eleven-, seven- and four-fold decrease in activity, respectively (Figure 1B, right panel).

A

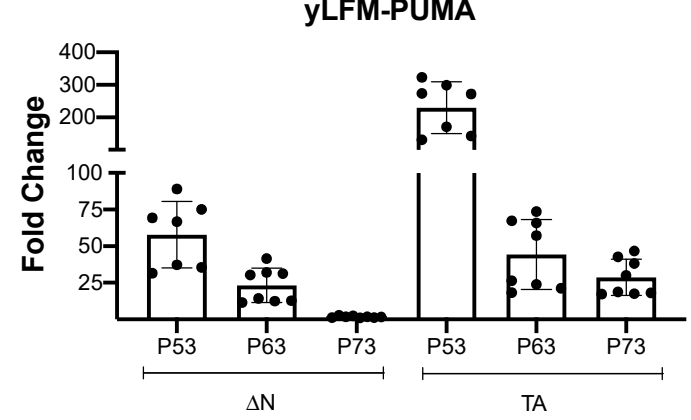

B

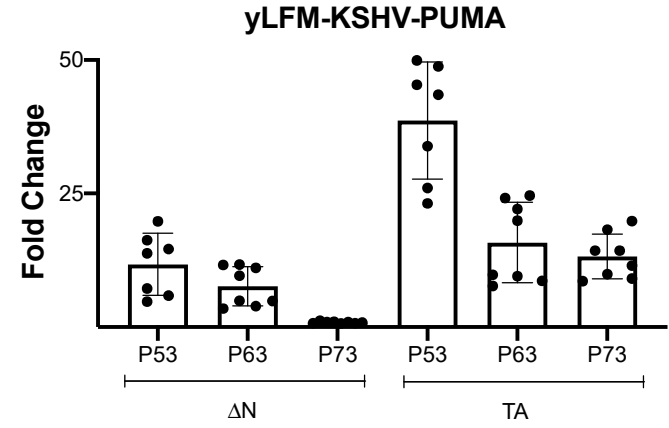

yLFM-KSHV

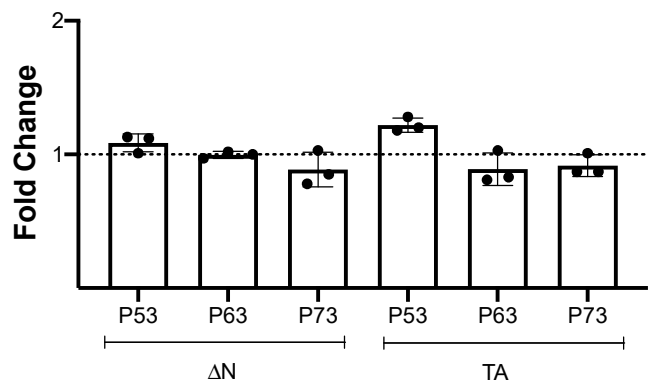

yLFM-PUMA-KSHV

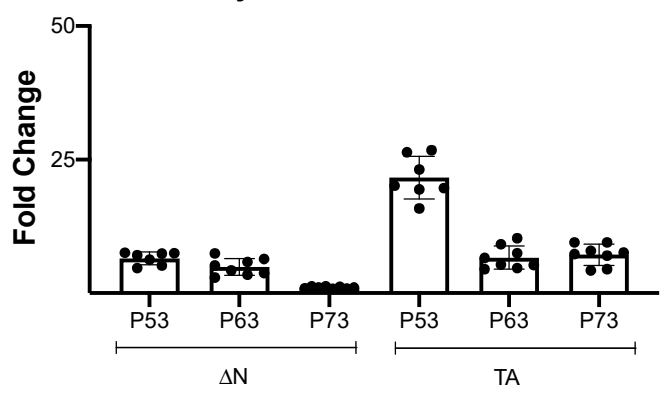

Figure 1. Fold change transactivation by wild-type P53 family proteins. Yeast cells expressing different P53 family isoforms by an inducible GAL1,10 promoter were grown for $8 \mathrm{~h}$ in Galactose $1 \%$ to evaluate their transactivation ability. (A) Evaluation of wild-type P53, P63, and P73 ( $\Delta \mathrm{N}$ variants: $\Delta \mathrm{N} 40 \mathrm{P} 53 \alpha, \Delta \mathrm{NP} 63 \alpha$, and $\Delta \mathrm{NP73} \alpha$; TA variants: full-length $\mathrm{P} 53, \mathrm{TAP} 63 \alpha$, and TAP73 $\alpha$ ) transcriptional activity as fold change over the empty vector in presence of the P53 response element (RE) from the PUMA target gene (yLFM-PUMA) or a G4 prone sequence (yLFM-KSHV). (B) Evaluation of transcriptional activity as in panel A in the presence of the G4 prone sequence upstream (yLFM-KSHV-PUMA) or downstream (yLFM-PUMA-KSHV) of the P53 RE from the PUMA target gene.

The results also showed that, independently from the presence of the G4 prone sequence, the TA variant from P53, P63, or P73 proteins is always significantly more active than the corresponding $\Delta \mathrm{N}$ variant (Figure 1A,B). However, the positioning of the 
G4 prone sequence downstream of the P53 RE (yLFM-PUMA-KSHV) leads to a slight but significant decrease in the relative activity of TA over $\Delta \mathrm{N}$ variants for both P53 (fulllength P53/ $\Delta \mathrm{N} 40 \mathrm{P} 53 \alpha$ ) and P63 (TAP63 $\alpha / \Delta \mathrm{NP} 63 \alpha$ ) (Figure 2A). Further, by comparing across $\mathrm{P} 53$ family proteins, the presence of the same G4 prone sequence either upstream or downstream of the RE (yLFM-KSHV-PUMA or yLFM-PUMA-KSHV, compared to yLFM-PUMA) significantly changes all relative activities, reducing the differences in transcriptional activity between different proteins of the P53 family, as highlighted by the significant increase in $\triangle \mathrm{NP} 63 \alpha$ /full-length P53, TAP63 $\alpha$ /full-length P53, and TAP73 $\alpha /$ fulllength $\mathrm{P} 53$ relative activity (Figure 2B).

A

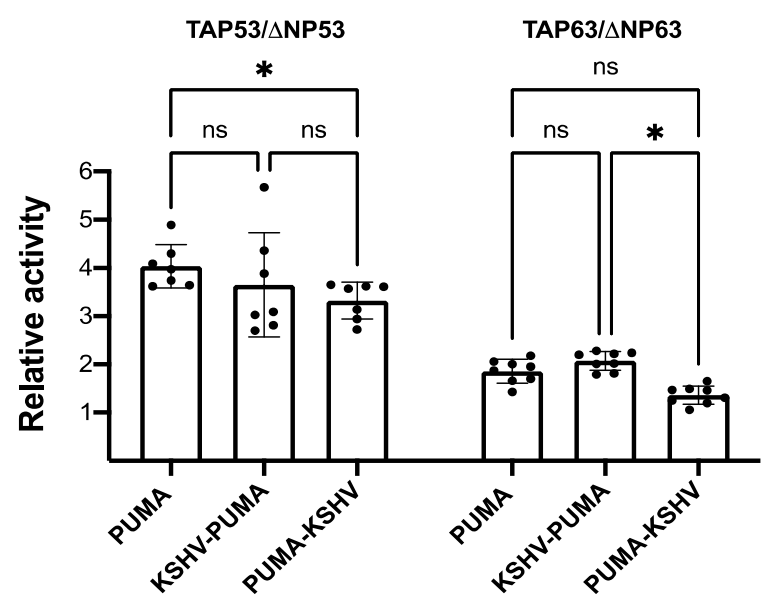

B

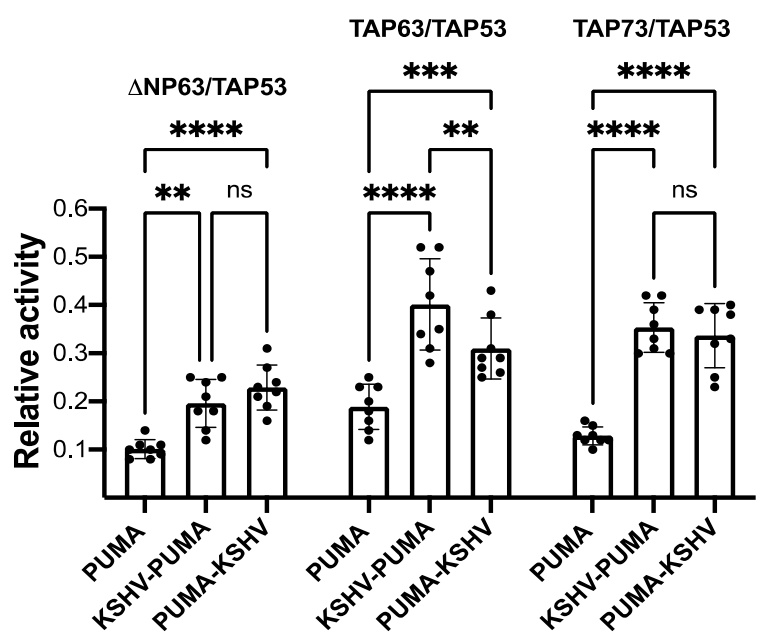

Figure 2. Relative activity of wild-type P53 family $\alpha$ isoforms. (A) Comparison of P53 (full-length P53) or P63 (TAP63 $\alpha$ ) TA variant activity with respect to the corresponding $\Delta \mathrm{N}$ variant $(\triangle \mathrm{N} 40 \mathrm{P} 53 \alpha$ and $\triangle$ NP63 $\alpha$, respectively) in yLFM-PUMA, yLFM-KSHV-PUMA, and yLFM-PUMA-KSHV strains. (B) Comparison of $\triangle \mathrm{NP} 63 \alpha$, TAP63 $\alpha$, or TAP73 $\alpha$ variant activity with respect to TAP53 (full-length P53) variant in yLFM-PUMA, yLFM-KSHV-PUMA, and yLFM-PUMA-KSHV strains. ns: not significant, ${ }^{*} p<0.05 ;{ }^{* *} p<0.01$; ${ }^{* * *} p<0.001$; ${ }^{* * * *} p<0.0001$.

3.2. The Presence of a G4 Prone Sequence Adjacent to a P53 RE Determines a Variation in the Relative Functionality of Mutant P53 and P63 Proteins

Since somatic and germ-line mutations are common to the TP53 gene in human cancers, while germ-line mutations at the TP63 locus, mainly affecting at protein level the $\triangle \mathrm{NP} 63 \alpha$ isoform, are involved in the development of P63-associated genetic disorders, we decided to extend the functional studies to mutant P53 family proteins. To this aim, the $\mathrm{P} 53 \mathrm{R} 175 \mathrm{H}$ and $\mathrm{R} 282 \mathrm{~W}$ proteins were selected (as full-length variants), being hot spot 
mutations both in sporadic cancers and Li-Fraumeni syndrome; the two mutants are also representative of a loss of function (i.e., R175H) and a partial function (i.e., R282W) mutant, respectively [42,44]. With regard to TP63 mutations, we selected the two $\triangle \mathrm{NP} 63 \alpha \mathrm{G} 134 \mathrm{~V}$ and $\triangle \mathrm{NP} 63 \alpha \mathrm{R} 204 \mathrm{~W}$ variants that we identified in patients affected by P63-associated disorders and that are representative of mutant proteins with greater or lesser functionality, respectively [41]. We previously confirmed that in our yeast model the observed differences in functional features of the selected P53 or P63 mutant proteins are not due to different levels of protein expression $[39,42]$.

The P53 R175H and $\Delta$ NP63 $\alpha$ R204W proteins are characterized by consistent loss of activity in all yeast strains independently from the presence of a G4 prone sequence (Figure 3A,B). The presence of the $\mathrm{G} 4$ prone sequence also causes an absolute reduction in the transactivation ability of the partial function mutant TAP53 R282W and $\Delta$ NP63 $\alpha$ G134V proteins. However, the presence of the G4 prone sequence downstream of the P53 RE significantly lowers the difference in activity with respect to the wild-type protein, especially for $\triangle \mathrm{NP} 63 \alpha \mathrm{G} 134 \mathrm{~V}$ mutant (i.e., $71 \%$ of wild-type functionality in yLFM-PUMAKSHV with respect to $28 \%$ in yLFM-PUMA) (Supplementary Figure S1).

A

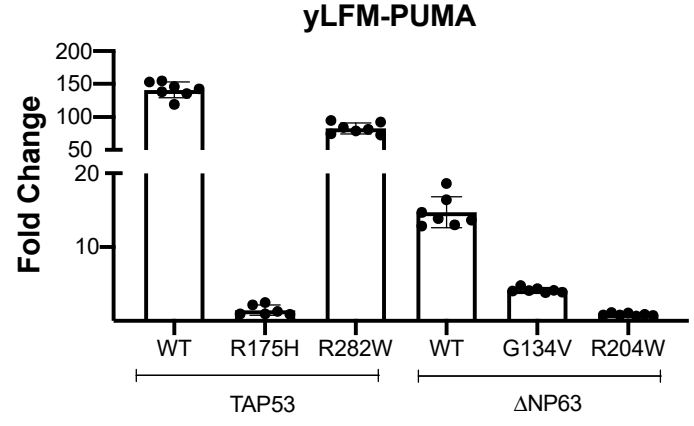

B

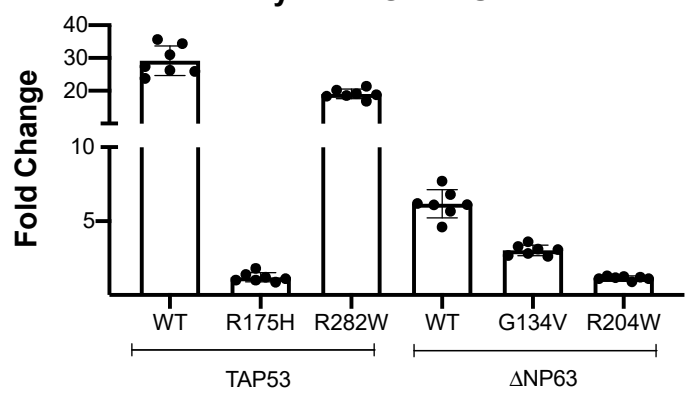

yLFM-KSHV

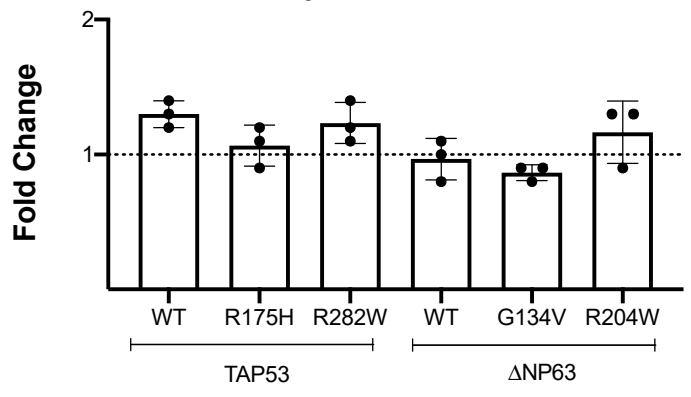

yLFM-PUMA-KSHV

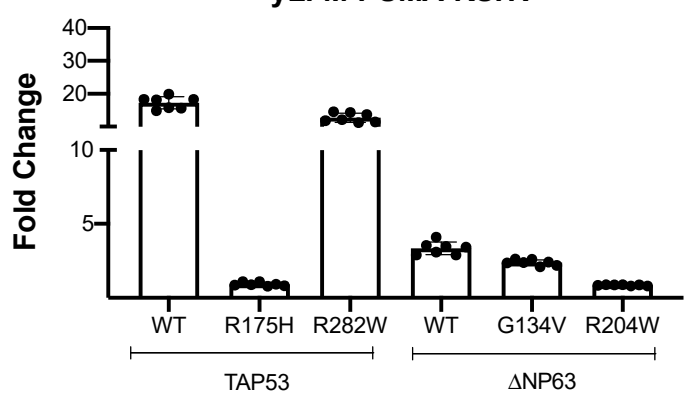

Figure 3. Fold change transactivation by mutant P53 family proteins. Yeast cells expressing wild-type and mutant TAP53 or $\triangle$ NP63 proteins by an inducible GAL1,10 promoter were grown for $8 \mathrm{~h}$ in Galactose $1 \%$ to evaluate the transactivation ability. (A) Evaluation of wild-type (TAP53: full-length P53; $\triangle$ NP63: $\triangle$ NP63 $\alpha$ ) or mutant (TAP53: R175H and R282W; $\triangle$ NP63: G134V and R204W) P53 and P63 proteins transcriptional activity as fold change over the empty vector in presence of the P53 RE from the PUMA target gene (yLFM-PUMA) or a G4 prone sequence (yLFM-KSHV). (B) Evaluation of transcriptional activity as in panel (A) in presence of the G4 prone sequence upstream (yLFM-KSHV-PUMA strain) or downstream (yLFM-PUMA-KSHV) of the P53 RE from the PUMA target gene. WT, wild-type.

As previously described, germ-line heterozygous mutations in the TP53 or TP63 gene are the molecular basis of the specific P53- and P63-related genetic disorders; then, it is conceivable that in the cells of affected patients, being P53 and P63 tetrameric TFs, wildtype, mixed, and mutant tetramers are formed. Based on this consideration, we simulated the heterozygous status in our yeast model by co-expressing wild-type and mutant P53 or P63 variants, and we evaluated the influence of the G4 prone sequence in this setting.

Although the presence of a G4 prone sequence causes the expected reduction in transactivation ability (Supplementary Figure S2; Supplementary Figure S3), it does not alter the 
potential for mutant P53 or P63 proteins to inhibit the corresponding wild-type-mediated transactivation, a feature known as dominant-negative or interfering ability [45]; in fact, the P53 R175H (full-length P53) and P63 R204W ( $\Delta$ NP63 $\alpha$ ) mutants that we previously described as dominant negative $[41-43,46]$ retain a comparable potential to inhibit wild-type activity also in the presence of the G4 prone sequence adjacent (upstream or downstream) to the P53 RE (Figure 4A,B).

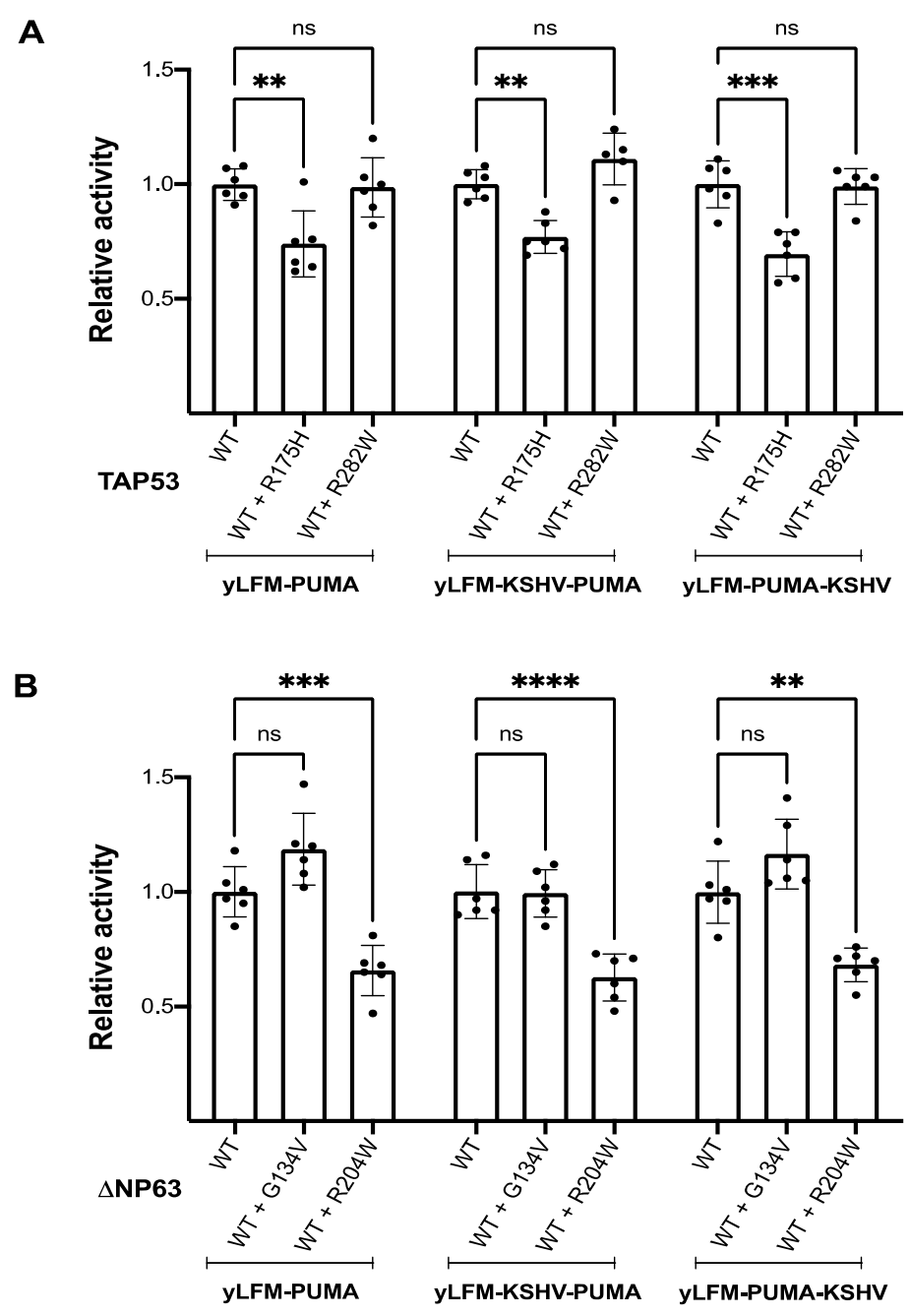

Figure 4. Relative activity of co-expressed wild-type and mutant TAP53 or $\triangle$ NP63 proteins compared to the corresponding single protein expression. (A) Comparison of wild-type and mutant TAP53 co-expression activity (i.e., constitutive pADH1-wild-type TAP53 + inducible pGAL1,10 TAP53 $\mathrm{R} 175 \mathrm{H}$ or R282W) with that of wild-type TAP53 expressed alone (i.e., constitutive pADH1-wild-type TAP53) in presence of the P53 RE from the PUMA target gene (yLFM-PUMA) or the same p53 RE along with a G4 prone sequence upstream (yLFM-KSHV-PUMA) or downstream (yLFM-PUMAKSHV). (B) Comparison of wild-type and mutant $\triangle \mathrm{NP} 63$ co-expression activity (i.e., constitutive pADH1-wild-type $\triangle$ NP63 + inducible pGAL1,10 $\triangle$ NP63 G134V or R204W) with that of wild-type $\triangle \mathrm{NP63}$ expressed alone (i.e., constitutive pADH1 wild-type $\triangle \mathrm{NP63}$ ) in presence of the P53 RE from the PUMA target gene (yLFM-PUMA) or the same P53 RE along with a G4 prone sequence upstream (yLFM-KSHV-PUMA) or downstream (yLFM-PUMA-KSHV). WT, wild-type. ns: not significant, ${ }^{* *} p<0.01 ;{ }^{* * *} p<0.001 ;{ }^{* * *} p<0.0001$.

\section{Discussion}

P53 family comprises a group of potent tetrameric TFs (i.e., P53, P63, and P73) sharing a conserved DNA binding domain responsible for the binding to sequence-specific DNA REs located near promoters of the target genes. Nevertheless, the transcriptional networks 
regulated by these proteins are largely distinct [47]; this feature is associated with the plasticity provided by the promoters (P1 and $\mathrm{P} 2$ ) and the splicing regulation of P53 family genes (N- and C-terminal isoforms), by the modulation of cofactors and companion TFs, and by the impact of quaternary structure of P53 family proteins at promoter target sites $[4,6,48]$.

Many studies have highlighted that RE recognition by P53 is regulated by the direct contacts with target DNA sequence; however, the so-called indirect readout provided by nucleotides within the RE that are not directly contacted by the P53 protein is also important $[49,50]$. This indirect readout, also referred to as "shape readout" since it appears to be related to structural properties at the P53 DNA target sites, has been recently extended to sequences surrounding the P53 RE [51].

Previously, we adapted a well-established yeast-based functional assay to evaluate the influence of a G4 DNA prone sequence in proximity of a P53 RE on the transactivation potential of full-length and N-terminal truncated P53 $\alpha$ isoforms [34]. Structurally, G4s are four-stranded nucleic acids structures held together by non-canonical Hoogsteen G-G base pairs [52,53]. G4 motifs are evolutionarily conserved from bacteria to human, confirming the importance of their formation in vivo [54]. In yeast and human, G4s are enriched in telomeric and ribosomal DNA, at transcriptional regulatory units, and at mitotic and meiotic double-strand break sites $[53,55,56]$. G4s can also form in RNA, where they can affect its stability or translation [57-60].

Indeed, contemporary research has demonstrated the importance of G4s in various cellular processes, including interactions with TFs [60-63]. Moreover, the targeting of the unique structure of G4s is proposed as a good tool for various diseases therapies including cancer [64-68].

Interestingly, G4s are often located in promoter sequences as shown for many human genes [69-71], including P53 targets; in fact, the presence of G4 prone sequences has been found around P53 RE in the promoter of the P53-induced apoptotic PUMA protein [34]. Therefore, the presence and the formation of a G4 structure could be an important transcriptional regulatory element, as previously observed in various organisms including humans [72-74].

In the present paper we extended for the first time the evaluation of the role of G4s in the transcription regulation to all P53 family proteins (wild-type and mutant $\alpha$ isoforms) by using the yeast Saccharomyces cerevisiae as model system; the impact of a sequence element prone to adopt a G4 secondary structure located upstream or downstream of the moderately active P53 RE from apoptotic PUMA target was evaluated. Moreover, the presence of G4 prone sequence is one of the possible reasons for binding of P53 to sites without a P53 RE as detected by ChIP studies [75]. However, we observed no significant activation of transcription by all analyzed proteins in presence of the G4 prone sequence alone, in agreement with the previous analysis regarding P53 protein [34]. On the contrary, we observed that the presence of the G4 prone sequence upstream, and more significantly downstream, of the RE causes inhibition of both $\Delta \mathrm{N}$ and TA variants P53 family protein-mediated transactivation. Interestingly, despite lacking a full-length transactivation domain, $\Delta \mathrm{N}$ isoforms are not transcriptionally inactive and have been shown to regulate the expression of their own set of genes [76-85]. The difference in relative transactivation between $\mathrm{TA}$ and $\Delta \mathrm{N}$ isoforms was, however, significantly reduced by the presence of the G4 prone sequence downstream of RE, which suggests that inhibition of transcription activity by G4 in this sequence context could be variant-dependent (i.e., stronger on TA than on $\Delta \mathrm{N}$ ).

Then, we decided to extend the study to P53 family protein mutants. To this aim, P53 and P63 mutations associated with specific genetic syndromes and functionally heterogeneous in terms of transactivation ability were selected; moreover, the chosen P53 mutations are also hot spot codons in human cancers. The presence of the G4 prone sequence (especially downstream of the P53 RE) tends to lower the difference between wild-type and mutant protein transactivation activity. Conversely, the simulation of heterozygous con- 
dition of P53- and P63-associated disorders by co-expressing wild-type and mutant P53 or P63 variants failed to reveal an impact of the G4 prone sequence on the dominant negative properties of the P53 R175H and P63 R204W mutations. However, it is to be taken into consideration that, P53 family proteins acting as tetramers, there is a variation in the modality by which tetramers are constituted and in the possible stoichiometry of hetero-tetramers comprising the combination of wild-type and missense mutations; thus, the adaptability of our yeast assay will allow further insights in this direction.

\section{Conclusions}

Overall, our data suggest that G4 prone sequences proximal to a P53 RE lead to an overall reduction of P53 family proteins-dependent transactivation. Still, at the same time, their presence can modulate the interplay between isoforms within the same protein and between different members of P53 family. Moreover, some functional features of mutant P53 family proteins can also be affected by the placement of a G4 prone sequence adjacent to a P53 RE. Hence, we propose that the sequence context surrounding a P53 RE can contribute to tuning P53 family proteins functions and should be considered as an important variable to fully characterize the P53 family cistrome. Furthermore, given that the net transcriptional effect of the P53 family proteins can be dependent on the ratio TA/ $\Delta \mathrm{N}$ variants of P53, P63, and P73 isoforms and on wild-type and mutant P53/P63/P73 interactions and binding to the promoters of target genes, our finding also paves the way for future studies involving the use of available small molecules that can modulate the conformations of G4s structure-forming DNA sequences [86].

Lastly, the yeast Saccharomyces cerevisiae has reconfirmed itself as a robust model system that can be turned into a sort of in vivo test-tube for the functional analysis of human TFs. Although the placement of a G4 prone sequence adjacent to a P53 RE within a minimal promoter can impact the site's global transactivation potential, our approach in yeast mainly focuses on the relative effect towards specific P53 family proteins or on their functional interactions. The otherwise isogenic nature of the reporter yeast strains and the regulated systems for ectopic protein expression we used give us confidence that the observed relative differences are not dependent on other variables.

Supplementary Materials: The following are available online at https: / www.mdpi.com/2073-4 425/12/2/277/s1, Figure S1: Relative activity of mutant P53 and P63 proteins, Figure S2: Fold change transactivation by co-expressed wild-type and mutant P53 proteins, Figure S3: Fold change transactivation by co-expressed wild-type and mutant P63 proteins.

Author Contributions: Conceptualization, P.M. (Paola Monti), V.B., A.I., G.F.; Writing-original draft preparation, P.M. (Paola Monti), V.B., A.I., G.F.; Methodology, P.M. (Paola Monti), V.B., N.B., O.P., P.M. (Paola Menichini), A.S., R.B., A.I., G.F.; Validation, P.M. (Paola Monti), V.B., N.B., O.P., P.M. (Paola Menichini), A.S., R.B., A.I., G.F.; Data curation, P.M. (Paola Monti), V.B., N.B., O.P., P.M. (Paola Menichini), A.S., R.B., A.I., G.F.; Writing-review and editing, P.M. (Paola Monti), V.B., N.B., O.P., P.M. (Paola Menichini), A.S., R.B., A.I., G.F. All authors have read and agreed to the published version of the manuscript.

Funding: This work was supported by AIRC I.G. n. 5506 (to G.F.), Italian Ministry of Health $5 \times 1000$ funds 2013, 2015, and 2016 (to G.F.), Current Research 2016 (to G.F.), Compagnia S. Paolo Turin Italy project 2017.0526 (to G.F.); by AIRC I.G. n.18985 (to A.I.); by the Czech Science Foundation n. 18-15548S (to V.B.).

Institutional Review Board Statement: Not applicable.

Informed Consent Statement: Not applicable.

Data Availability Statement: Not applicable.

Conflicts of Interest: The authors declare no conflict of interest. 


\section{References}

1. Lane, D.P.; Crawford, L.V. T Antigen is bound to a host protein in SV40-transformed cells. Nature 1979, 278, 261-263. [CrossRef]

2. Kaghad, M.; Bonnet, H.; Yang, A.; Creancier, L.; Biscan, J.-C.; Valent, A.; Minty, A.; Chalon, P.; Lelias, J.-M.; Dumont, X.; et al. Monoallelically expressed gene related to P53 at 1p36, a region frequently deleted in neuroblastoma and other human cancers. Cell 1997, 90, 809-819. [CrossRef]

3. Yang, A.; Kaghad, M.; Wang, Y.; Gillett, E.; Fleming, M.D.; Dötsch, V.; Andrews, N.C.; Caput, D.; McKeon, F. P63, a P53 homolog at 3q27-29, encodes multiple products with transactivating, death-inducing, and dominant-negative activities. Mol. Cell 1998, 2, 305-316. [CrossRef]

4. Collavin, L.; Lunardi, A.; Del Sal, G. P53-family proteins and their regulators: Hubs and spokes in tumor suppression. Cell Death Differ. 2010, 17, 901-911. [CrossRef]

5. Wei, J.; Zaika, E.; Zaika, A. P53 family: Role of protein isoforms in human cancer. J. Nucleic Acids 2012, 2012, 687359. [CrossRef] [PubMed]

6. Bourdon, J.-C. P53 family isoforms. CPB 2007, 8, 332-336. [CrossRef]

7. Malkin, D. Li-Fraumeni syndrome. Genes Cancer 2011, 2, 475-484. [CrossRef]

8. Mills, A.A.; Zheng, B.; Wang, X.-J.; Vogel, H.; Roop, D.R.; Bradley, A. P63 is a P53 homologue required for limb and epidermal morphogenesis. Nature 1999, 398, 708-713. [CrossRef]

9. Rinne, T.; Brunner, H.G.; van Bokhoven, H. P63-associated disorders. Cell Cycle 2007, 6, 262-268. [CrossRef]

10. Rufini, A.; Agostini, M.; Grespi, F.; Tomasini, R.; Sayan, B.S.; Niklison-Chirou, M.V.; Conforti, F.; Velletri, T.; Mastino, A.; Mak, T.W.; et al. P73 in cancer. Genes Cancer 2011, 2, 491-502. [CrossRef] [PubMed]

11. Nemajerova, A.; Moll, U.M. Tissue-specific roles of P73 in development and homeostasis. J. Cell Sci. 2019, 132, jcs233338. [CrossRef] [PubMed]

12. Menendez, D.; Inga, A.; Resnick, M.A. The expanding universe of P53 targets. Nat. Rev. Cancer 2009, 9, 724-737. [CrossRef] [PubMed]

13. Riley, T.; Sontag, E.; Chen, P.; Levine, A. Transcriptional control of human P53-regulated genes. Nat. Rev. Mol. Cell Biol. 2008, 9, 402-412. [CrossRef] [PubMed]

14. El-Deiry, W.S.; Kern, S.E.; Pietenpol, J.A.; Kinzler, K.W.; Vogelstein, B. Definition of a consensus binding site for P53. Nat. Genet. 1992, 1, 45-49. [CrossRef] [PubMed]

15. Brandt, T.; Petrovich, M.; Joerger, A.C.; Veprintsev, D.B. Conservation of DNA-binding specificity and oligomerisation properties within the P53 family. BMC Genom. 2009, 10, 628. [CrossRef]

16. Perez, C.A.; Ott, J.; Mays, D.J.; Pietenpol, J.A. P63 Consensus DNA-binding site: Identification, analysis and application into a P63MH algorithm. Oncogene 2007, 26, 7363-7370. [CrossRef] [PubMed]

17. Osada, M.; Park, H.L.; Nagakawa, Y.; Yamashita, K.; Fomenkov, A.; Kim, M.S.; Wu, G.; Nomoto, S.; Trink, B.; Sidransky, D. Differential recognition of response elements determines target gene specificity Forp53 and P63. MCB 2005, 25, 6077-6089. [CrossRef]

18. Moll, U.M.; Slade, N. P63 and P73: Roles in development and tumor formation. Mol. Cancer Res. 2004, 2, $371-386$.

19. Zheng, X.; Chen, X. Aquaporin 3, a glycerol and water transporter, is regulated by P73 of the P53 family. FEBS Lett. 2001, 489, 4-7. [CrossRef]

20. Nakagawa, T.; Takahashi, M.; Ozaki, T.; Watanabe, K.; Todo, S.; Mizuguchi, H.; Hayakawa, T.; Nakagawara, A. Autoinhibitory regulation of $\mathrm{P} 73$ by $\triangle \mathrm{Np} 73$ to modulate cell survival and death through a P73-specific target element within the $\Delta \mathrm{Np} 73$ promoter. MCB 2002, 22, 2575-2585. [CrossRef]

21. Sasaki, Y.; Ishida, S.; Morimoto, I.; Yamashita, T.; Kojima, T.; Kihara, C.; Tanaka, T.; Imai, K.; Nakamura, Y.; Tokino, T. The P53 family member genes are involved in the notch signal pathway. J. Biol. Chem. 2002, 277, 719-724. [CrossRef]

22. Harms, K.; Nozell, S.; Chen, X. The common and distinct target genes of the P53 family transcription factors. Cell. Mol. Life Sci. 2004, 61, 822-842. [CrossRef]

23. Brázda, V.; Coufal, J. Recognition of local DNA structures by P53 protein. Int. J. Mol. Sci. 2017, 18, 375. [CrossRef]

24. Jagelská, E.B.; Brázda, V.; Pečinka, P.; Paleček, E.; Fojta, M. DNA Topology influences P53 sequence-specific DNA binding through structural transitions within the target sites. Biochem. J. 2008, 412, 57-63. [CrossRef]

25. Coufal, J.; Jagelská, E.B.; Liao, J.C.C.; Brázda, V. Preferential binding of P53 tumor suppressor to P21 promoter sites that contain inverted repeats capable of forming cruciform structure. Biochem. Biophys. Res. Commun. 2013, 441, 83-88. [CrossRef] [PubMed]

26. Petr, M.; Helma, R.; Polášková, A.; Krejčí, A.; Dvořáková, Z.; Kejnovská, I.; Navrátilová, L.; Adámik, M.; Vorlíčková, M.; Brázdová, M. Wild-type P53 binds to MYC promoter G-quadruplex. Biosci. Rep. 2016, 36, e00397. [CrossRef]

27. Brázda, V.; Fojta, M. The rich world of P53 DNA binding targets: The role of DNA structure. Int. J. Mol. Sci. 2019, 20, 5605. [CrossRef] [PubMed]

28. Quante, T.; Otto, B.; Brázdová, M.; Kejnovská, I.; Deppert, W.; Tolstonog, G.V. Mutant P53 is a transcriptional co-factor that binds to g-rich regulatory regions of active genes and generates transcriptional plasticity. Cell Cycle 2012, 11, 3290-3303. [CrossRef] [PubMed]

29. Kennedy, B.K. Mammalian transcription factors in yeast: Strangers in a familiar land. Nat. Rev. Mol. Cell Biol. 2002, 3, 41-49. [CrossRef] [PubMed] 
30. Schärer, E.; lggo, R. Mammalian P53 can function as a transcription factor in yeast. Nucleic Acids Res. 1992, $20,1539-1545$. [CrossRef]

31. Sharma, V.; Monti, P.; Fronza, G.; Inga, A. Human transcription factors in yeast: The fruitful examples of P53 and NF-KB. FEMS Yeast Res. 2016, 16, fow083. [CrossRef] [PubMed]

32. Storici, F.; Lewis, L.K.; Resnick, M.A. In vivo site-directed mutagenesis using oligonucleotides. Nat. Biotechnol. 2001, 19, 773-776. [CrossRef]

33. Monti, P.; Bosco, B.; Gomes, S.; Saraiva, L.; Fronza, G.; Inga, A. Yeast as a chassis for developing functional assays to study human P53. J. Vis. Exp. 2019, 150. [CrossRef]

34. Porubiaková, O.; Bohálová, N.; Inga, A.; Vadovičová, N.; Coufal, J.; Fojta, M.; Brázda, V. The influence of quadruplex structure in proximity to P53 target sequences on the transactivation potential of P53 alpha isoforms. Int. J. Mol. Sci. 2019, 21, 127. [CrossRef]

35. Storici, F.; Resnick, M.A. Delitto perfetto targeted mutagenesis in yeast with oligonucleotides. Genet. Eng. N. Y. 2003, 25, 189-207.

36. Resnick, M.A.; Inga, A. Functional mutants of the sequence-specific transcription factor P53 and implications for master genes of diversity. Proc. Natl. Acad. Sci. USA 2003, 100, 9934-9939. [CrossRef] [PubMed]

37. Inga, A.; Storici, F.; Darden, T.A.; Resnick, M.A. Differential transactivation by the P53 transcription factor is highly dependent on P53 level and promoter target sequence. MCB 2002, 22, 8612-8625. [CrossRef]

38. Andreotti, V.; Ciribilli, Y.; Monti, P.; Bisio, A.; Lion, M.; Jordan, J.; Fronza, G.; Menichini, P.; Resnick, M.A.; Inga, A. P53 Transactivation and the impact of mutations, cofactors and small molecules using a simplified yeast-based screening system. PLoS ONE 2011, 6, e20643. [CrossRef]

39. Monti, P.; Russo, D.; Bocciardi, R.; Foggetti, G.; Menichini, P.; Divizia, M.T.; Lerone, M.; Graziano, C.; Wischmeijer, A.; Viadiu, H.; et al. EEC- and ADULT-associated TP63 mutations exhibit functional heterogeneity toward P63 responsive sequences. Hum. Mutat. 2013, 34, 894-904. [CrossRef]

40. Ciribilli, Y.; Monti, P.; Bisio, A.; Nguyen, H.T.; Ethayathulla, A.S.; Ramos, A.; Foggetti, G.; Menichini, P.; Menendez, D.; Resnick, M.A.; et al. Transactivation specificity is conserved among P53 family proteins and depends on a response element sequence code. Nucleic Acids Res. 2013, 41, 8637-8653. [CrossRef]

41. Monti, P.; Ciribilli, Y.; Bisio, A.; Foggetti, G.; Raimondi, I.; Campomenosi, P.; Menichini, P.; Fronza, G.; Inga, A. $\Delta$ N-P63 $\alpha$ and TA-P63 $\alpha$ exhibit intrinsic differences in transactivation specificities that depend on distinct features of DNA target sites. Oncotarget 2014, 5, 2116-2130. [CrossRef] [PubMed]

42. Monti, P.; Lionetti, M.; De Luca, G.; Menichini, P.; Recchia, A.G.; Matis, S.; Colombo, M.; Fabris, S.; Speciale, A.; Barbieri, M.; et al. Time to first treatment and P53 dysfunction in chronic lymphocytic leukaemia: Results of the O-CLL1 study in early stage patients. Sci. Rep. 2020, 10, 18427. [CrossRef] [PubMed]

43. Monti, P.; Perfumo, C.; Bisio, A.; Ciribilli, Y.; Menichini, P.; Russo, D.; Umbach, D.M.; Resnick, M.A.; Inga, A.; Fronza, G. Dominant-negative features of mutant TP53 in germline carriers have limited impact on cancer outcomes. Mol. Cancer Res. 2011, 9, 271-279. [CrossRef]

44. Zhang, Y.; Coillie, S.V.; Fang, J.-Y.; Xu, J. Gain of function of mutant P53: R282W on the peak? Oncogenesis 2016, 5, e196. [CrossRef]

45. Ko, L.J.; Prives, C. P53: Puzzle and paradigm. Genes Dev. 1996, 10, 1054-1072. [CrossRef] [PubMed]

46. Monti, P.; Campomenosi, P.; Ciribilli, Y.; Iannone, R.; Inga, A.; Abbondandolo, A.; Resnick, M.A.; Fronza, G. Tumour P53 mutations exhibit promoter selective dominance over wild type P53. Oncogene 2002, 21, 1641-1648. [CrossRef]

47. Dötsch, V.; Bernassola, F.; Coutandin, D.; Candi, E.; Melino, G. P63 and P73, the ancestors of P53. Cold Spring Harb. Perspect. Biol. 2010, 2, a004887. [CrossRef]

48. Ferraiuolo, M.; Di Agostino, S.; Blandino, G.; Strano, S. Oncogenic intra-P53 family member interactions in human cancers. Front. Oncol. 2016, 6, 77. [CrossRef] [PubMed]

49. Kitayner, M.; Rozenberg, H.; Rohs, R.; Suad, O.; Rabinovich, D.; Honig, B.; Shakked, Z. Diversity in DNA recognition by P53 revealed by crystal structures with hoogsteen base pairs. Nat. Struct. Mol. Biol. 2010, 17, 423-429. [CrossRef]

50. Beno, I.; Rosenthal, K.; Levitine, M.; Shaulov, L.; Haran, T.E. Sequence-dependent cooperative binding of P53 to DNA targets and its relationship to the structural properties of the DNA targets. Nucleic Acids Res. 2011, 39, 1919-1932. [CrossRef]

51. Senitzki, A.; Safieh, J.; Sharma, V.; Golovenko, D.; Danin-Poleg, Y.; Inga, A.; Haran, T.E. The complex architecture of P53 binding sites. Nucleic Acids Res. 2021. [CrossRef]

52. Lipps, H.J.; Rhodes, D. G-quadruplex structures: In vivo evidence and function. Trends Cell Biol. 2009, 19, 414-422. [CrossRef]

53. Marsico, G.; Chambers, V.S.; Sahakyan, A.B.; McCauley, P.; Boutell, J.M.; Antonio, M.D.; Balasubramanian, S. Whole genome experimental maps of DNA G-quadruplexes in multiple species. Nucleic Acids Res. 2019, 47, 3862-3874. [CrossRef] [PubMed]

54. Spiegel, J.; Adhikari, S.; Balasubramanian, S. The structure and function of DNA G-quadruplexes. Trends Chem. 2020, 2, $123-136$. [CrossRef] [PubMed]

55. Huppert, J.L. Structure, location and interactions of G-quadruplexes. FEBS J. 2010, 277, 3452-3458. [CrossRef] [PubMed]

56. Capra, J.A.; Paeschke, K.; Singh, M.; Zakian, V.A. G-quadruplex DNA sequences are evolutionarily conserved and associated with distinct genomic features in Saccharomyces cerevisiae. PLoS Comput. Biol. 2010, 6, e1000861. [CrossRef]

57. Huppert, J.L. Hunting G-quadruplexes. Biochimie 2008, 90, 1140-1148. [CrossRef]

58. Morris, M.J.; Basu, S. An unusually stable G-quadruplex within the 5'-UTR of the MT3 matrix metalloproteinase MRNA represses translation in eukaryotic cells. Biochemistry 2009, 48, 5313-5319. [CrossRef] 
59. Agarwala, P.; Pandey, S.; Mapa, K.; Maiti, S. The G-quadruplex augments translation in the $5^{\prime}$ untranslated region of transforming growth factor B2. Biochemistry 2013, 52, 1528-1538. [CrossRef]

60. Dumas, L.; Herviou, P.; Dassi, E.; Cammas, A.; Millevoi, S. G-quadruplexes in RNA biology: Recent advances and future directions. Trends Biochem. Sci. 2020. [CrossRef]

61. Rhodes, D.; Lipps, H.J. G-quadruplexes and their regulatory roles in biology. Nucleic Acids Res. 2015, 43, 8627-8637. [CrossRef]

62. Hároníková, L.; Coufal, J.; Kejnovská, I.; Jagelská, E.B.; Fojta, M.; Dvořáková, P.; Muller, P.; Vojtesek, B.; Brázda, V. IFI16 preferentially binds to DNA with quadruplex structure and enhances DNA quadruplex formation. PLoS ONE 2016, 11, e0157156. [CrossRef]

63. Dhamodharan, V.; Pradeepkumar, P.I. Specific recognition of promoter G-quadruplex DNAs by small molecule ligands and light-up probes. ACS Chem. Biol. 2019, 14, 2102-2114. [CrossRef] [PubMed]

64. Kharel, P.; Balaratnam, S.; Beals, N.; Basu, S. The role of RNA G-quadruplexes in human diseases and therapeutic strategies. WIREs RNA 2020, 11, e1568. [CrossRef]

65. Chaudhuri, R.; Bhattacharya, S.; Dash, J.; Bhattacharya, S. Recent update on targeting c-MYC G-quadruplexes by small molecules for anticancer therapeutics. J. Med. Chem. 2020, 64, 42-70. [CrossRef] [PubMed]

66. Sanchez-Martin, V.; Lopez-Pujante, C.; Soriano-Rodriguez, M.; Garcia-Salcedo, J.A. An updated focus on quadruplex structures as potential therapeutic targets in cancer. Int. J. Mol. Sci. 2020, 21, 8900. [CrossRef]

67. Asamitsu, S.; Yabuki, Y.; Ikenoshita, S.; Wada, T.; Shioda, N. Pharmacological prospects of G-quadruplexes for neurological diseases using porphyrins. Biochem. Biophys. Res. Commun. 2020, 531, 51-55. [CrossRef] [PubMed]

68. Kawauchi, K.; Urano, R.; Kinoshita, N.; Kuwamoto, S.; Torii, T.; Hashimoto, Y.; Taniguchi, S.; Tsuruta, M.; Miyoshi, D. Photosensitizers based on G-quadruplex ligand for cancer photodynamic therapy. Genes 2020, 11, 1340. [CrossRef]

69. Bedrat, A.; Lacroix, L.; Mergny, J.-L. Re-evaluation of G-quadruplex propensity with G4Hunter. Nucleic Acids Res. 2016, 44, 1746-1759. [CrossRef]

70. Lago, S.; Nadai, M.; Ruggiero, E.; Tassinari, M.; Marušič, M.; Tosoni, B.; Frasson, I.; Cernilogar, F.M.; Pirota, V.; Doria, F.; et al. The MDM2 inducible promoter folds into four-tetrad antiparallel G-quadruplexes targetable to fight malignant liposarcoma. Nucleic Acids Res. 2021, 49, 847-863. [CrossRef]

71. Da Ros, S.; Nicoletto, G.; Rigo, R.; Ceschi, S.; Zorzan, E.; Dacasto, M.; Giantin, M.; Sissi, C. G-quadruplex modulation of SP1 functional binding sites at the KIT proximal promoter. Int. J. Mol. Sci. 2020, 22, 329. [CrossRef]

72. Brázda, V.; Hároníková, L.; Liao, J.; Fojta, M. DNA and RNA quadruplex-binding proteins. Int. J. Mol. Sci. 2014, 15, 17493-17517. [CrossRef] [PubMed]

73. Gazanion, E.; Lacroix, L.; Alberti, P.; Gurung, P.; Wein, S.; Cheng, M.; Mergny, J.-L.; Gomes, A.R.; Lopez-Rubio, J.-J. Genome wide distribution of G-quadruplexes and their impact on gene expression in malaria parasites. PLoS Genet. 2020, 16, e1008917. [CrossRef]

74. Chashchina, G.V.; Beniaminov, A.D.; Kaluzhny, D.N. Stable G-quadruplex structures of oncogene promoters induce potassiumdependent stops of thermostable DNA polymerase. Biochem. Mosc. 2019, 84, 562-569. [CrossRef] [PubMed]

75. Nguyen, T.-A.T.; Grimm, S.A.; Bushel, P.R.; Li, J.; Li, Y.; Bennett, B.D.; Lavender, C.A.; Ward, J.M.; Fargo, D.C.; Anderson, C.W.; et al. Revealing a human P53 universe. Nucleic Acids Res. 2018, 46, 8153-8167. [CrossRef] [PubMed]

76. Kartasheva, N.N.; Lenz-Bauer, C.; Hartmann, O.; Schäfer, H.; Eilers, M.; Dobbelstein, M. $\Delta$ Np73 can modulate the expression of various genes in a P53-independent fashion. Oncogene 2003, 22, 8246-8254. [CrossRef] [PubMed]

77. King, K.E.; Ponnamperuma, R.M.; Yamashita, T.; Tokino, T.; Lee, L.A.; Young, M.F.; Weinberg, W.C. $\Delta$ Np63 $\alpha$ functions as both a positive and a negative transcriptional regulator and blocks in vitro differentiation of murine keratinocytes. Oncogene 2003, 22, 3635-3644. [CrossRef] [PubMed]

78. Kazantseva, M.; Mehta, S.; Eiholzer, R.A.; Hung, N.; Wiles, A.; Slatter, T.L.; Braithwaite, A.W. A Mouse model of the $\Delta 133$ p53 isoform: Roles in cancer progression and inflammation. Mamm. Genome 2018, 29, 831-842. [CrossRef]

79. Ghioni, P.; Bolognese, F.; Duijf, P.H.G.; van Bokhoven, H.; Mantovani, R.; Guerrini, L. Complex transcriptional effects of P63 isoforms: Identification of novel activation and repression domains. MCB 2002, 22, 8659-8668. [CrossRef]

80. Barton, C.E.; Johnson, K.N.; Mays, D.M.; Boehnke, K.; Shyr, Y.; Boukamp, P.; Pietenpol, J.A. Novel P63 target genes involved in paracrine signaling and keratinocyte differentiation. Cell Death Dis. 2010, 1, e74. [CrossRef]

81. Dohn, M.; Zhang, S.; Chen, X. P63 $\alpha$ and $\Delta \mathrm{Np} 63 \alpha$ can induce cell cycle arrest and apoptosis and differentially regulate P53 target genes. Oncogene 2001, 20, 3193-3205. [CrossRef] [PubMed]

82. Romano, R.-A.; Ortt, K.; Birkaya, B.; Smalley, K.; Sinha, S. An active role of the $\Delta \mathrm{N}$ isoform of P63 in regulating basal keratin genes K5 and K14 and directing epidermal cell fate. PLoS ONE 2009, 4, e5623. [CrossRef]

83. Wu, G.; Osada, M.; Guo, Z.; Fomenkov, A.; Begum, S.; Zhao, M.; Upadhyay, S.; Xing, M.; Wu, F.; Moon, C.; et al. DeltaNp63alpha up-regulates the Hsp70 gene in human cancer. Cancer Res. 2005, 65, 758-766.

84. Higashikawa, K.; Yoneda, S.; Tobiume, K.; Saitoh, M.; Taki, M.; Mitani, Y.; Shigeishi, H.; Ono, S.; Kamata, N. $\Delta$ Np63 $\alpha$-dependent expression of Id-3 distinctively suppresses the invasiveness of human squamous cell carcinoma. Int. J. Cancer 2009, 124, 2837-2844. [CrossRef] [PubMed]

85. Kommagani, R.; Leonard, M.K.; Lewis, S.; Romano, R.-A.; Sinha, S.; Kadakia, M.P. Regulation of VDR by Np63 is associated with inhibition of cell invasion. J. Cell Sci. 2009, 122, 2828-2835. [CrossRef] [PubMed]

86. del Mundo, I.M.A.; Vasquez, K.M.; Wang, G. Modulation of DNA structure formation using small molecules. Biochim. Biophys. Acta Mol. Cell Res. 2019, 1866, 118539. [CrossRef] [PubMed] 